Abstract THU0196 - Table 1. Hazardratios among patients starting their first biologic treatment during the studyperiod according to contextual factors

\begin{tabular}{|c|c|c|c|c|}
\hline & $\begin{array}{l}\text { Infliximab } \\
\text { originator }\end{array}$ & \begin{tabular}{|l|} 
Iffliximab \\
biosimilar
\end{tabular} & $\begin{array}{l}\text { Etanercept } \\
\text { originator }\end{array}$ & $\begin{array}{l}\text { Etanercept } \\
\text { biosimilar }\end{array}$ \\
\hline Number of patients & 368 & 738 & 125 & 2079 \\
\hline $\begin{array}{l}\text { Number of } \\
\text { discontinuations }\end{array}$ & 165 & 265 & 23 & 392 \\
\hline \multicolumn{5}{|l|}{ Dept. size } \\
\hline Low (quartile | \& II) & $0.88(0.37-2.11)$ & $1.47(0.88-2.46)$ & $30.66(6.16-152.68)$ & $1.69(1.12-2.55)$ \\
\hline Medium (quartile III) & $1.29(0.81-2.08)$ & $1.90(1.36-2.65)$ & $10.96(2.13-56.49)$ & $1.40(1.08-1.82)$ \\
\hline High (quartile IV) & Ref & Ref & Ref & Ref \\
\hline \multicolumn{5}{|l|}{ Dept. use of biosimilars } \\
\hline Low & Ref & Ref & Ref & Ref \\
\hline High & $0.88(0.58-1.34)$ & $1.20(0.82-1.75)$ & $1.90(0.64-5.70)$ & $1.00(0.77-1.29)$ \\
\hline \multicolumn{5}{|c|}{\begin{tabular}{l|l} 
Period of biologic start & \\
\end{tabular}} \\
\hline Early period & Ref & Ref & Ref & Ref \\
\hline & (7-1.42) & $0.65(0.50-0.85$ & $0.06(0.01-0.53) \S$ & 17) \\
\hline
\end{tabular}

*Additionally adjusted for department size and use of biosimilar;

$\S$ Only 2 discontinuation in the later period of etanercept originator

Conclusions: Contextual factors, presumably related to expectations and differences in clinical monitoring, influence the observed survival on drug of biologics, including biosimilars, and must be considered when the comparative effectiveness of biosimilars is evaluated.

Disclosure of Interest: D. DiGiuseppe: None declared, T. Frisell: None declared, E. Lindqvist: None declared, L. Jacobsson Consultant for: received lecture and consulting fees from Pfizer, Abbvie and Novartis, C. Turesson Grant/ research support from: Abbvie, Bristol Myers-Squibb, Roche, Consultant for: MSD, Bristol Myers-Squibb, Roche, Paidinstructor for: Abbvie, Bristol-Myers Squibb, Janssen, MSD, Pfizer, Roche and UCB, C. Sjöwall: None declared, J. Askling Grant/research support from: has orhas had research agreements with Abbvie, BMS, MSD, Pfizer, Roche, Astra-Zeneca, Eli Lilly, Samsung Bioepis, and UCB, mainly in the context of safety monitoring of biologics via ARTIS. Karolinska Institutet has received remuneration for JA participating in advisory boards arranged by Pfizer and Eli Lilly.

DOI: 10.1136/annrheumdis-2018-eular.4464

\section{THU0197 EFFECTS OF TOCILIZUMAB, AN ANTI-INTERLEUKIN-6 RECEPTOR ANTIBODY, ON SERUM LIPID AND ADIPOKINE LEVELS IN PATIENTS WITH RHEUMATOID ARTHRITIS}

E. Hoffman ${ }^{1}$, M.A. Rahat ${ }^{1,2}$, J. Feld ${ }^{3}$, M. Elias ${ }^{3}$, I. Rosner ${ }^{1,4}$, L. Kaly ${ }^{4}$, I. Lavi ${ }^{5}$, D. Zisman ${ }^{1,3} .{ }^{1}$ The Ruth and Bruce Rappaport Faculty of Medicine, Technion; ${ }^{2}$ The Immunotherapy Laboratory; ${ }^{3}$ Rheumatology Unit, Carmel Medical Center, ${ }^{4}$ Rheumatology Unit, Bnai Zion Medical Center, ${ }^{5}$ Department of Community Medicine and Epidemiology, Carmel Medical Center, Haifa, Israel

Background: Patients with rheumatoid arthritis (RA) are at increased risk of cardiovascular disease. ${ }^{1}$ Dyslipidemia is a known adverse reaction to tocilizumab (TCZ), the anti-interleukin-6 receptor antibody, used in RA treatment.

Objectives: To assess the effect of TCZ on lipid and adipokine levels in the serum of RA patients

Methods: Forty RA patients with active disease initiating TCZ treatment and 40 healthy matched controls were included. Height, weight, disease activity score (DAS28), lipid profile and atherogenic indices (AI) were measured before and four months after TCZ treatment initiation. Serum concentrations of leptin, adiponectin, resistin, interleukin- 6 and high sensitivity CRP were measured by ELISA in both study groups.

Statistical analysis: The differences in clinical and laboratory data of RA patients between baseline and follow up were assessed by paired t-test and by linear mixed models with repeated measures for adipokines levels after adjustment to BMI, statin treatment and disease duration. To compare the adipokines levels between RA and control groups adjusted to baseline BMI and statin treatment we used ANCOVA models. HsCRP and IL- 6 were compared between the two groups by two-tailed Mann Whitney test. The results were considered statistically significant when $\mathrm{p} \leq 0.05$.

Results: The average age of the study population was $57.5 \pm 11$ years, $82.5 \%$ were women, with a disease duration of $8.7 \pm 5.6$ years. The majority of the patients responded to TCZ and reduced their diseases activity from DAS28 score of 5.45 \pm 1.06 to $3.46 \pm 1.37$ ( $p<0.0001)$. Following treatment, a significant elevation of total cholesterol $(199 \pm 52$ to $221 \pm 53 \mathrm{mg} / \mathrm{dl}, \mathrm{p}<0.01)$, HDL $(55 \pm 19$ to $59 \pm 23 \mathrm{mg} / \mathrm{dl}$, $\mathrm{p}<0.01)$ and triglycerides $(140 \pm 69$ to $168 \pm 107, p=0.04)$, and no significant changes in weight, BMI, low density lipoprotein (LDL) and Al were found. Significantly higher adiponectin levels $(5.59 \pm 2.39 \mathrm{vs}$. $3.75 \pm 1.63 \mathrm{ng} / \mathrm{ml}, \mathrm{p}<0.0001)$, lower resistin levels $(16.25 \pm 7.17$ vs. $21.53 \pm 8.19 \mathrm{pg} / \mathrm{ml}, p=0.007)$ and leptin/adiponectin ratio $(6.44 \pm 6.44$ vs.5.52 $\pm 6.08, p=0.03)$ were measured in the RA group compared to controls after adjustment to BMI and statin treatment. Four months after TCZ treatment a statistically significant decrease in adiponectin (4.53 $\pm 2.12 \mathrm{ng} / \mathrm{ml} \mathrm{p}<0 / 0001)$, resistin levels $(20.42 \pm 8.06 \mathrm{pg} / \mathrm{ml}, \mathrm{p}=0.01)$ and leptin/adiponectin ratio $(7.99 \pm 7.84, p=0.002)$ were measured after adjustment to BMI, statin treatment and disease duration. The levels of hsCRP decreased significantly
(3.37 \pm 2.0 vs $0.74 \pm 1.36 \mathrm{mg} / \mathrm{dl}, \mathrm{p}<0.001)$ and IL-6 increased significantly $(13.15$ \pm 25.43 vs $99.80 \pm 97.97 \mathrm{pg} / \mathrm{ml}, \mathrm{p}<0.001$ ) following treatment.

Conclusions: The impact of TCZ treatment on lipid metabolism is complex. The elevation in $\mathrm{HDL}$ without change in $\mathrm{Al}$, and the tendency toward normalisation of the adipokine profile observed, suggests a protective role of TCZ treatment against the cardiovascular burden in RA patients.

\section{REFERENCE:}

[1] Lago F, Gomez R, et al. Cardiometabolic comorbidities and rheumatic diseases: focus on the role of fat mass and adipokines. Arthritis Care Res $2011 ; 63: 1083-90$

Disclosure of Interest: None declared

DOI: 10.1136/annrheumdis-2018-eular.4418

\section{THU0198 IMMUNOGENICITY ASSOCIATED WITH A TRANSITION FROM ADALIMUMAB REFERENCE PRODUCT TO ABP 501 IN PATIENTS WITH RHEUMATOID ARTHRITIS}

E. Krishnan, D. Mytych, N. Zhang, H. Wang, A. Kaliyaperumal. Biosimilars Development, Amgen Inc., Thousand Oaks, USA

Background: In clinical practice, patients treated with an originator product may be transitioned to a biosimilar. Therefore, it is important to ensure that such transition is safe and is not associated with increased immunogenicity.

Objectives: To study the incidence of binding anti-drug antibodies (bADAs) and neutralising anti-drug antibodies (nADAs) after patients with rheumatoid arthritis (RA) are transitioned from adalimumab reference product (RP) to ABP 501, an approved biosimilar for adalimumab.

Methods: We analysed data from the open-label extension (OLE) of a randomised 26 week phase 3 study (NCT 01970475) comparing ABP 501 and adalimumab. In this OLE study (NCT02114931), patients originally randomised to ABP 501 in the parent study continued on ABP 501 while patients originally randomised to adalimumab (RP) were switched to ABP 501 so that all patients received ABP 501. Specifically, we studied the incidence of new ADAs in patients who were ADA negative at the time of entry into the OLE study. The incidence after excluding transiently elevated ADAs was also examined.

Results: The Table summarises the incidence of ADAs.

Abstract THU0198 - Table 1

\begin{tabular}{|l|c|c|}
\hline Original randomization arm & $\begin{array}{c}\text { ABP 501/ } \\
\text { ABP 501 }\end{array}$ & $\begin{array}{c}\text { Adalimumab RF/ } \\
\text { ABP 501 }\end{array}$ \\
\hline $\begin{array}{l}\text { Number of patients with negative bADA at } \\
\text { oLE baseline }\end{array}$ & 147 & 149 \\
\hline New oases of +bADA post OLE baseline & 50 & 35 \\
\hline New cases of +nADA post OLE baseline & 20 & 12 \\
\hline Transient cases of +bADA & 33 & 13 \\
\hline Transient cases of + nADA & 8 & 2 \\
\hline Overall incidence of new cases of +bADA & $34.0 \%$ & $23.5 \%$ \\
\hline Overall incidence of new cases of +nADA & $13.6 \%$ & $8.1 \%$ \\
\hline Incidence of non-transient cases of +bADA & $11.6 \%$ & $14.8 \%$ \\
\hline Incidence of non-transient cases of +nADA & $8.2 \%$ & $6.7 \%$ \\
\hline
\end{tabular}

Conclusions: Transitioning from adalimumab reference product to ABP 501 was not associated with increased immunogenicity over the observational period of 72 weeks.

Disclosure of Interest: E. Krishnan Shareholder of: Amgen Inc., Employee of: Amgen Inc., D. Mytych Shareholder of: Amgen Inc., Employee of: Amgen Inc., N. Zhang Shareholder of: Amgen Inc., Employee of: Amgen Inc., H. Wang Shareholder of: Amgen Inc., Employee of: Amgen Inc., A. Kaliyaperumal Shareholder of: Amgen Inc., Employee of: Amgen Inc.

DOI: 10.1136/annrheumdis-2018-eular.7225

\section{THU0199 A PILOT STUDY TO ASSESS THE RELATIONSHIP BETWEEN SMOKING AND DRUG INEFFICACY IN RHEUMATOID ARTHRITIS - PART OF A QUALITY IMPROVEMENT PROJECT AIMED AT SMOKING CESSATION}

G. Starritt, D. Brennan. Rheumatology, Musgrave Park Hospital, Belfast Health and Social Care Trust, Belfast, UK

Background: It has long been known that patients with rheumatoid arthritis who smoke have more severe disease. This results in greater joint destruction and dis ability, and further increase in cardiovascular risk ${ }^{1}$. Patients' disease may be more difficult to control with disease modifying anti-rheumatic drugs (DMARDs) and biologic drugs. Smoking may also interfere with the pharmacokinetics of biologic 